\title{
First Impressions: A Review of Diversity-related Content on North American LIS Program Websites
}

Ana Ndumu, Florida State University, USA

Crystal Betts-Green, Florida State University, USA

\begin{abstract}
This study explores library and information science (LIS) program websites from a recruitment and marketing standpoint and sheds light on the availability of diversityrelated content. LIS and higher education literature suggests that the Internet and program websites are crucial when it comes to prospective students' graduate school selection. Using Berelson's (1952) quantitative content analysis technique, the researchers examined faculty profiles, diversity statements, diversity-related courses, funding opportunities, achievements, and student organizations on program websites. The data indicates that, collectively, LIS programs are successful in sharing information on funding as well as highlighting faculty scholarship related to diversity. Greater emphasis could be placed on crafting and displaying diversity statements; designing, offering, and listing diversityrelated courses beyond survey courses; consistently showcasing diversity-related achievements and events; and encouraging and supporting diversity-related student groups. This research has implications for fostering more strategic diversity-related initiatives.
\end{abstract}

Keywords: diversity; LIS education; marketing; recruitment; social justice

Publication Type: research article

\section{Introduction}

$\mathrm{L}$ ibrary and information science (LIS) educators in the U.S. and Canada have been paying closer attention to diversity in the information professions. Topics of discussion have included promoting intercultural leadership and cultural competence skills (e.g., Allard, Mehra, \& Qayyum, 2007), embedding diversity and intercultural issues within the LIS curriculum (e.g., Abdullahi, 2007; Cooke \& Sweeney, 2017; Subramaniam \& Jaeger, 2011), increasing representation and inclusion within the LIS professorate (e.g., Jaeger \& Franklin, 2007; Subramaniam \& Jaeger, 2010), and recruiting and retaining specific marginalized groups (e.g., Lloyd, 2007; Lance, 2005). In the past, proponents of diversity efforts (e.g., Adkins \& Espinal, 2004; Jaeger, Subramanian, Jones, \& Bertot, 2011; Cooke, 2013) have noted the wide representational gap within the field and the professorate. Very little has changed. Recent data by the Association for Library \& Information Science Education (ALISE, 2017) and the American Library Association (ALA, 2017) substantiates that racial and ethnic representation among North American LIS professionals and educators have not reached parity with combined Canadian and U.S. demographics. Consider the following:

- American Indians or Alaskan Natives comprise $.042 \%$ of the library workforce and $.01 \%$ of the LIS professorate, even though this group totals $5.2 \%$ of the 
overall North American population

- Hispanics comprise $6 \%$ of the library workforce and 3\% of the professorate, despite making up $15 \%$ of the overall North American population

- Blacks or African Americans comprise $9 \%$ of the library workforce and $4 \%$ of the professorate, even though they make up $12.6 \%$ of the North American population

- Asians or Pacific Islanders comprise $4.4 \%$ of the library workforce and $13 \%$ of the professorate while comprising $8 \%$ of the North American population

- Whites comprise $80 \%$ of the library workforce and $76 \%$ of the professorate while comprising $72 \%$ of the North American population

Despite the $3 \%$ of respondents who declined to respond or identified as more than one race, the statistics demonstrate a disparity.

Add to this conundrum the fact that, in our field, diversity as a construct remains “maddeningly vague," as Hudson $(2017$, p. 6) describes it. Definitions vary widely across contexts and purposes. Although diversity is widely construed within LIS, researchers and practitioners often document the lack of race and ethnicity in the field. It is generally agreed (ALA, 2017; ALISE, 2017; Cooke \& Sweeney, 2017; Subramanian \& Jaeger, 2011), however, that diversity spans beyond race or ethnicity and entails age, socioeconomic status, religion, gender, sexual orientation, language, physical and learning disabilities, and beyond.

In keeping with the spirit of inclusion, this study takes into account as many facets of diversity as possible, as defined within LIS in the U.S. and Canada. The central theme of our research is not which definition of diversity is the most accurate, but that a critical part of recruiting a diverse LIS workforce involves demonstrating inclusion and representation. We address the impact of LIS program websites in engaging and appealing to potential LIS students who are interested in civil rights or might benefit from social justice initiatives. This research focuses on LIS education in North America, but the findings and recommendations should inform LIS educators in other parts of the world, especially in countries where there is a need to diversify the profession. As researchers from underrepresented backgrounds, a global scope is particularly important to us.

More significantly, this article echoes the growing ethical and critical sentiment (Caidi \& Dali, 2015; Cooke \& Sweeney, 2017; Dali \& Caidi, 2017; Hastings, 2015; Hudson, 2017; Mehra \& Rioux, 2016) that diversity efforts need to mature beyond perfunctory undertakings to more substantive and relevant measures. Rather than approaching diversity as the right thing to do (Dali \& Caidi, 2017; Cooke \& Sweeney, 2017), it must be positioned as a value so integral to our profession that it is grafted within LIS programs and workplaces. Our study of LIS program websites is intended to appraise whether the values of equity, diversity, and social justice are noticeable to students. Attention to the takenfor-granted aspects of recruitment such as a program's website, or "virtual face" (Wilson \& Meyer, 2009), may reveal the extent to which the field's interest in inclusion and representation translates into online spaces. Since LIS education is increasingly delivered online-and, even when it is delivered face-to-face, promotion and marketing heavily rely 
on online presence-it stands to reason that potential students will begin their investigations of programs online. This study is intended to discern the impressions that program websites collectively convey to prospective students.

\section{Background}

LIS has long entertained the notion of diversity but has yet to fully embrace its promise (Gibson et al., 2017; Hudson, 2017). To date, the LIS diversity paradigm has largely depended on evangelically recruiting students of color (Kim \& Sin, 2006; 2008; Morgan, Farrar, \& Owens, 2009). As evidenced by stagnant diversity statistics, however, the outcomes have been hollow. Since programs center on embodied diversity-that is, the presence of people from non-white or non-dominant groups in the LIS classroom-there has been very little structural or epistemological progress. It is time for "integral diversity," or "diversity by design," to quote Dali \& Caidi (2017), or "a natural state of diversity," according to Hastings (2015). In other words, diversity needs to become more than simply a proposition; it must be a praxis (hooks, 1994). This mandate calls for intentionality in all spaces and aspects of the LIS program.

Enrolling those who are considered "others" has been the order of the day in LIS programs and workspaces (Hudson, 2017). Yet, few studies examine student preferences; a great deal of our reflections on diversity have resulted in analyst-constructed typologies (Marshall \& Rossman, 1999). We argue that student-centered investigations can influence epistemic change. To this end, Kim and Sin (2006) found that research on the viewpoints of LIS students of color, the target group of most recruitment and retention aims, is scarce. The results of their survey study demonstrate that, besides financial support and work opportunities, students from diverse backgrounds seek to take part in proactive and progressive education "that is embraced and supported by the entire LIS community" ( $\mathrm{p}$. 89). More recently, Caidi and Dali (2015) investigated student perceptions of and preferences for LIS education. Their findings suggest that while students often prefer to select programs based on pragmatic considerations (i.e., location, costs), program values and missions are also important. Subsequent research (Dali \& Caidi, 2016) indicated that the Internet was the second most utilized tool for program selection. Over 50 percent of surveyed students expressed that online information was their primary guidance. The authors argue that "considering that some recruitment, outreach and targeted advertisements by LIS programs are also done online, the importance of the Internet may be even greater" (Dali \& Caidi, 2016, p. 511). It is this finding that the current study seeks to probe.

It can be argued that LIS professionals and educators have long grown accustomed to digital media. Many educators are mindful of the centrality of the Internet to the domain and the ways in which the web and information and communication technology (ICT) mediated education impact LIS professionalization. The fact that the Internet is intrinsic to LIS means that we must perpetually scrutinize correlative power dynamics. It is necessary for program websites to encapsulate this awareness. For potential students, especially those for whom distance or online education is novel, the Internet-program websites, in particular-have important implications which need to be brought to the forefront. The overarching question, then, is what impression of equity, diversity, and social justice prospective students get based on program websites.

Furthermore, to truly transform diversity-related outcomes in the information professions,

The International Journal of Information, Diversity, \& Inclusion, 2(3), 2018

ISSN 2574-3430, publish.lib.umd.edu/IJIDI/ 
it is critical to draw from research beyond LIS. We borrow from higher education literature, which corroborates that program websites serve as the primary information-gathering tools for prospective graduate students (Dam, 2014). Unlike with long-standing higher education marketing and recruitment vehicles such as college fairs and print paraphernalia, the quality of program websites is less dependent on the size and budget of the institution (Pegoraro, 2006). For LIS schools, websites can be a cost-effective means of highlighting diversity efforts to prospective students, allowing smaller programs, despite limited resources, to compete with their larger counterparts in terms of projecting core values and departmental images (Kirp, 2003; Pegoraro, 2006).

When it comes to investing in graduate school, finding the right fit is vital. Selecting a program is a multistage process that typically begins with online discovery. Thus, the Internet has emerged as the single most important tool in the college search (Gordon \& Berhow, 2009; Poock \& Lefond, 2003). While a university's main site is useful for attracting undergraduates (Wilson \& Meyer, 2009), program websites primarily attract graduate students and must therefore include some key characteristics (Maringe, 2006; Poock \& Lefond, 2003). Attention to diversity can be appealing to students from diverse backgrounds as well as anyone for whom diversity efforts matter. For example, departmental statements can convey a program's commitment to creating a healthy learning environment and providing equal opportunities for those on the margins of society (Saichaie, 2011; Saichaie \& Morphew, 2014; Smith et al., 2016). Diversity statements are great starting points. To be convincing, however, websites need substantive diversity related content that goes beyond declared values. The best approach is for institutions to provide learning environments and for websites to make it easy to discern successes along these lines.

Perceptions of the departmental social climate have been found to influence graduate student choice in college (Kallio, 1995). Whether pursuing on-campus or distance education, students of ten base their decisions not only on the program rank and resources, but also on potential relationships or experiences. According to Rau and Hyland (2003), person-organization theory suggests that individuals who embrace egalitarianism and seek a culture of diversity often give more weight to a welcoming departmental atmosphere than to tuition costs or degree requirements. In the same vein, Greenberg (1990) found that recruits are attracted to the organizations that are committed to diversity if they perceive themselves to be the potential beneficiaries of diversity practices and policies. In other words, an LIS program's website can represent its pledge to equity, diversity, and social justice and, in doing so, welcome prospective students.

\section{Research Questions}

To investigate whether ALA-accredited LIS program websites present diversity-related content, the following research questions were devised:

1. To what extent do LIS school websites provide diversity statements?

2. To what extent do LIS school websites provide information on diverse student groups?

3. To what extent do LIS school websites provide information on funding opportunities for diverse students? 
4. To what extent do LIS school websites provide information on diversity-related student activities?

5. To what extent do LIS school websites provide information on diversity-related courses?

\section{Methods}

The researchers accessed the directory of sixty-one ALA-accredited programs and visited program websites between June 21 and September 28, 2017. They utilized Berelson's (1952) quantitative content analysis approach to evaluate each program website according to an established protocol to compute the presence of diversity statements, listings of diverse student groups, availability of funding opportunities for diverse students, and posts of diversity-related initiatives or entities. This data collection technique allows for analyzing written content in a systematic, objective, quantitative manner to measure variables. Content analysis quantifies the presence of words, concepts, themes, or sentences.

In order to assess the characteristics of diversity statements and related material, the researchers mined and categorized available content with the goal of identifying prevalent words and critical word strings. The data was later synthesized and compared based on emergent themes derived from word frequencies.

\section{Analysis}

\section{RQ1: Diversity Statements}

Diversity statements are proclamations of a commitment to diversity. The field's leading organizations, including the ALA and ALISE, have published formal diversity statements to guide information professionals. Diversity statements can also help draft newcomers to the field, attract more diverse pools of applicants, and function as launching points for strategic initiatives.

In this study, a diversity statement is operationalized as a stand-alone, exclusive statement on equity, diversity, and social justice. It is complementary to but distinct from values and mission statements. Such a statement may be a diversity plan or a specific policy address, and must express an LIS program's position on diversity in lieu of a link to or copy of a university's statement. Fourteen $(23 \% ; \mathrm{N}=61)$ LIS school websites provide access to diversity statements, and Table 1 provides a sample of them (in alphabetical order). An analysis of diversity statements indicates that diversity, information, inclusion, and community are among the 15 most common words (Table 2) when allowing for stemmed words, and their relevance increases after adding the following supererogatory words to the stop word list: faculty, students, educators, researchers, staff, university, iSchool, program, and school. Weighted percentages are based on the frequency of the word relative to the total words counted. The weighted percentage assigns a portion of the word's frequency to each group so that the overall total does not exceed $100 \%$. Weights also allow for accurate contextual analysis of word frequencies.

Similarly, 51 program websites $(84 \% ; \mathrm{N}=61)$ contained statements on missions, visions, and goals. Operationally, missions, visions, and goals are statements on the future direction of 
an LIS program. Missions, visions, and goals can be presented independently as subsidiary webpages or within other documents, such as a program's strategic plan. The data suggests that thirty-one, or roughly half, of the online programs' missions, visions, and goals statements reference "diversity," "multicultural," "inclusion," "representation," or any truncation or derivative of these terms. Moreover, an examination of published missions, visions, and goals (when using the same rubric for mining diversity statements) indicates that of the four above-mentioned words, "diversity" recurs frequently and places sixth (weighted percentage $0.97 \%$ ) among the 15 most commonly used words, as presented in Table 3.

Table 1. Examples of diversity statements

\begin{tabular}{|c|c|}
\hline Institution & $\overline{\text { URL }}$ \\
\hline Kent State University & $\begin{array}{l}\text { https://www.kent.edu/iSchool/diversity-inclusion- } \\
\text { statement }\end{array}$ \\
\hline University of Maryland & https://ischool.umd.edu/diversity-initiatives \\
\hline University of Michigan & https://www.si.umich.edu/aboutsi/diversity-school- \\
\hline $\begin{array}{l}\text { University of North Carolina, } \\
\text { Chapel Hill }\end{array}$ & $\begin{array}{l}\text { https://sils.unc.edu/about/diversityhttps: //sils.unc.edu/a } \\
\text { bout/diversity }\end{array}$ \\
\hline University of Washington & https://ischool.uw.edu/ \\
\hline
\end{tabular}

Table 2. Word frequencies - Program diversity statements ( $\mathrm{N}=5,021$ words)

\begin{tabular}{llll}
\hline Word & Related Words & $\begin{array}{l}\text { Frequency } \\
\text { (n) }\end{array}$ & $\begin{array}{l}\text { Weighted } \\
\text { Percentage (\%) }\end{array}$ \\
\hline diversity & diverse & 242 & 4.82 \\
information & inform & 103 & 2.05 \\
inclusion & inclusive, inclusively, inclusiveness, & 87 & 1.73 \\
& inclusivity & 76 & 1.51 \\
community & communities & 62 & 1.24 \\
library & libraries & 38 & 0.76 \\
issues & issue & 38 & 0.76 \\
promote & promotes, promoting, promotion, & & \\
& promotions & 36 & 0.72 \\
research & researchers & 35 & 0.7 \\
development & develop, developed, developing & 31 & 0.62 \\
professional & professional, professionalism, professionals & 30 & 0.6 \\
recruitment & recruit, recruiting & 29 & 0.58 \\
equity & equality & 29 & 0.58 \\
technology & technological, technologies & 28 & 0.56 \\
access & accessibility, accessible & 28 & 0.56 \\
create & created, creates, creating & & \\
\hline
\end{tabular}


Table 3. Word frequency - Program missions, visions, and goals ( $\mathrm{N}=7,766$ words)

\begin{tabular}{llll}
\hline Word & Related Words & Frequency (n) & $\begin{array}{l}\text { Weighted Percentage } \\
(\%)\end{array}$ \\
\hline professional & $\begin{array}{l}\text { professionalism, professionally, } \\
\text { professionals }\end{array}$ & 146 & 1.88 \\
research & researchers, researching & 24 & 1.6 \\
service & services & 93 & 1.2 \\
community & communities, communities' & 84 & 1.08 \\
knowledge & knowledgeable & 77 & 0.99 \\
diversity & diverse & 75 & 0.97 \\
environment & environments & 44 & 0.57 \\
global & globally & 37 & 0.48 \\
access & accessed, accessibility, & 33 & 0.43 \\
& accessible, accessing & & 0.4 \\
commitment & commitments, committed & 31 & 0.4 \\
people & peoples' & 31 & 0.37 \\
leaders & leadership & 29 & 0.28 \\
articulate & articulates & 22 & 0.28 \\
contribute & contributes, contribution, & 22 & 0.23 \\
& contributions & 18 & \\
achieve & achieves, achievement & & \\
\hline
\end{tabular}

\section{RQ2: Diversity-Related Student Groups}

LIS applicants who belong to underrepresented groups or who wish to use their career to support these populations will find that $25(40 \%$; $N=61)$ programs sponsor multicultural or diversity-related student organizations (see Appendix A). Our examination pinpoints that diversity-related LIS student groups focus on general diversity and social justice awareness (12), women in the information professions (12), minority groups or specific ethnic groups (9), the lesbian, gay, bisexual, transgender, and queer (LGBTQ) community (4), international libraries or librarianship (6), and incarcerated persons (1). Five programs sponsor peer/mentor or diversity ambassador groups whereby student volunteers serve as contacts for prospective students by providing tours of the schools and the host institution and directing prospective student to relevant resources. Based on our findings, it appears that there are no LIS student groups that support senior citizens or those with disabilities or, at least, this information is not easily discernable from the descriptions of respective groups. A list of student organizations by type is provided in Appendix A.

\section{RQ3: Funding}

To date, efforts to strengthen inclusion and representation in LIS have overwhelmingly consisted of providing financial resources for students of color. Our review of LIS program websites indicates that 50 programs $(81 \% ; \mathrm{N}=61)$ provide partial or full funding in the form of departmental or endowed scholarships for students from underrepresented backgrounds. 
While fellowships and scholarships are too numerous to list, it is important to mention a few current large-scale scholarship or fellowship opportunities that serve as examples of concerted diversity-related efforts. The University of Arizona Knowledge River program, a project funded by the U.S. Institute of Museum and Library Services (IMLS) to educate information professionals who have experience with and are committed to the information needs of Latinx and Native American populations, has graduated 170 LIS professionals and scholars (the majority of whom are themselves of Native American or Latinx descent) since its inception (University of Arizona, 2017). Similarly, La SCALA (Latino Scholars Cambio Leadership Academy), another IMLS-funded program, in partnership with the University of Tennessee-Knoxville and the University of Arizona, provides full funding for Latinx students to obtain their doctorates in LIS (University of Tennessee, 2017). Wayne State University's Project IDOL (Increasing Diversity of Librarians), yet another IMLS-funded initiative, is a collaboration between the Wayne State University School of Information and Historically Black Colleges and Universities (HBCU) Library Alliance, a library consortium that provides training and support for the 104 historically Black colleges and universities recognized by the White House. This three-year project has focused on recruiting, mentoring, and providing an online MLIS degree to ten students from historically underrepresented groups. Wayne State University oversees the project and executes the educational component while the HBCU Library Alliance leads the mentoring component and assists with student recruitment (Wayne State University, 2017).

\section{RQ4: Diversity-Related Activities and Achievements}

Students who value diversity or identify as students with diverse backgrounds may be more likely to explore the program website for faculty profiles, departmental news, or program achievements that relate to social justice and multiculturalism, believing that such highlights are indicators of potential academic support and student experience (Gordon \& Berhow, 2009; Maringe, 2006; Saichaie, 2011; Saichaie \& Morphew, 2014). A significant pull factor is that prospective graduate students typically seek to collaborate with faculty members who share similar interests.

The data on program websites shows that all 61 programs list faculty profiles and research. Additionally, $42(69 \% ; \mathrm{N}=61)$ program websites include social justice-related achievements, events, and news. Content ranges from conference and association awards (i.e., Association of Research Libraries Diversity Scholar); to diversity research grants (i.e., the ALA diversity research grant, Beta Phi Mu Lancour scholarship for foreign study); recent faculty publications on diversity and social justice; faculty and student participation in national and international conferences; study abroad or service opportunities; and fundraising for community events. Furthermore, several programs have established diversity-related symposiums or conferences (Table 4) or institutes or centers (Table 5).

\section{RQ5: Diversity-Related Courses}

Prospective graduate students are also likely to peruse information about course offerings. A catalog of available courses is an important resource for those who are interested in training or professional development that advance services for underrepresented groups along with cultural competence in the information professions.

A review of program sites reveals that 48 LIS programs (78\%) provide access to an online listing of courses. Within the available listings, there are 132 diversity-related courses on topics such 
as race and ethnicity; gender and sexuality; usability, access, and ethics; services to specific populations; globalization and international aspects of LIS; and community engagement. A complete list of diversity-related courses is provided in Appendix B. Based on available information, it appears that most programs offer an average of three diversity-related courses, the majority of which are survey courses, while five programs offer a significant number of diversity-related courses (10-12) along with diversity-related certificates or concentrations (Table 6). By this measure, these five programs produce nearly 40 percent of diversity-related courses. This, of course, does not represent how frequently these courses are offered, which is potentially more important than the existence of course offerings.

Table 4. Diversity-related symposiums or conferences

\begin{tabular}{|c|c|}
\hline Program & Event \\
\hline University of Illinois & $\begin{array}{l}\text { Libraries Serving Refugees \& Asylum Seekers Summit } \\
\text { https://publish.illinois.edu/projectwelcome/summit/ }\end{array}$ \\
\hline University of Maryland & $\begin{array}{l}\text { Conference on Inclusion \& Diversity in LIS } \\
\text { http: / /ipac.umd.edu/content/cidlis-2017 }\end{array}$ \\
\hline Simmons & $\begin{array}{l}\text { DERAIL Conference } \\
\text { https: / / lisedforum.wordpress.com/ }\end{array}$ \\
\hline University of Toronto & $\begin{array}{l}\text { Diversity by Design Symposium } \\
\text { https://www.idiversitybydesign.com/ }\end{array}$ \\
\hline $\begin{array}{l}\text { University of } \\
\text { Washington }\end{array}$ & $\begin{array}{l}\text { Diversity Summit } \\
\text { https://ischool.uw.edu/diversity/events-programs }\end{array}$ \\
\hline $\begin{array}{l}\text { Western University, } \\
\text { Ontario }\end{array}$ & $\begin{array}{l}\text { Organizing Equality International Conference } \\
\text { http://organizingequality.com/ }\end{array}$ \\
\hline
\end{tabular}

Table 5. Diversity-related centers or institutes

\begin{tabular}{|c|c|}
\hline Program & Center or Institute \\
\hline Drexel University & $\begin{array}{l}\text { Center for the Study of Libraries, Information \& Society } \\
\text { http: / /drexel.edu/cci/research/centers-institutes/CSLIS/ }\end{array}$ \\
\hline $\begin{array}{l}\text { Florida State } \\
\text { University }\end{array}$ & Information Use Management \& Policy Institute https://www.ii.fsu.edu/ \\
\hline University of & Center for Digital Inclusion \\
\hline Illinois, Urbana- & http://cdi.ischool.illinois.edu/ \\
\hline Champagne & $\begin{array}{l}\text { Mortenson Center for International Library Programs } \\
\text { https://www.library.illinois.edu/mortenson/ }\end{array}$ \\
\hline University of & Information Policy and Access Center (iPAC) \\
\hline Maryland & https://ischool.umd.edu/search/node/ipac \\
\hline University of & iSchool Inclusion Institute for the Information Science (i3) \\
\hline Pittsburgh & http://www.sis.pitt.edu/i3/ \\
\hline University of & iDEA (Diversity, Equity, \& Access) Project \\
\hline Washington & https://ischool.uw.edu/diversity/events-programs/idea-project \\
\hline
\end{tabular}

Additionally, 15 programs provide access to a number of diversity-related courses through the Web-based Information Science Education (WISE) consortia that allows LIS students to enroll in distance courses at other institutions while receiving credit toward their degree. 
Diversity-related courses offered through WISE include Literature \& Bibliography: Sources \& Services for Patrons with a Disability; Information Services for Specific Populations; Globalization and the Information Society: Information, Communication \& Development; Feminism, Librarianship \& Information; and Female Voices in Historical Narratives (WISE, 2017).

Table 6. Diversity-related certificates or concentrations

\begin{tabular}{|c|c|}
\hline Program & Certificate or concentration \\
\hline $\begin{array}{l}\text { University of } \\
\text { Alabama } \\
\text { University of } \\
\text { British } \\
\text { Columbia }\end{array}$ & $\begin{array}{l}\text { Social Justice degree concentration } \\
\text { https: //slis.ua.edu/curriculum/mlis-areas-of-emphasis/ } \\
\text { First Nations certificate } \\
\text { https: //slais.ubc.ca/programs/degree-specializations/first-nations- } \\
\text { curriculum-concentration/ } \\
\text { Community \& Culture Pathway } \\
\text { https: //slais.ubc.ca/community-and-culture/ }\end{array}$ \\
\hline $\begin{array}{l}\text { Catholic } \\
\text { University }\end{array}$ & $\begin{array}{l}\text { Community \& Embedded Librarian concentration } \\
\text { http://lis.cua.edu/MSinLS/coursesStudy/community-embedded.cfm }\end{array}$ \\
\hline $\begin{array}{l}\text { University of } \\
\text { Maryland }\end{array}$ & $\begin{array}{l}\text { Diversity \& Inclusion certificate } \\
\text { https://ischool.umd.edu/sites/default/files/page_files/diversityandinclusion2 } \\
\text {.pdf }\end{array}$ \\
\hline $\begin{array}{l}\text { University of } \\
\text { North } \\
\text { Carolina, } \\
\text { Chapel Hill }\end{array}$ & $\begin{array}{l}\text { Diversity Advocate certificate } \\
\text { https://sils.unc.edu/about/diversity/certificate }\end{array}$ \\
\hline
\end{tabular}

\section{Discussion}

This article explored whether there is congruence between the LIS field's efforts to diversify versus what LIS programs represent on their sites. Although research (e.g., Caidi \& Dali, 2015; Dali \& Caidi, 2016; Dam 2014; Saichaie, 2014; Saichaie \& Morphew, 2014) supports that a potential advantage exists for programs that demonstrate diversity on their platforms, our review of LIS program websites reveals that this potential is not fully realized. Taken as a whole, LIS programs are successful in sharing information on funding and in highlighting faculty scholarship related to diversity. While important to inclusion and representation, both of these practices focus on the largely solo endeavors of seeking resources or going about LIS research. Our findings imply that greater emphasis can be placed on crafting and displaying diversity statements; designing, offering, and/or listing diversity-related courses beyond survey courses; showcasing diversity-related achievements and events; and encouraging and supporting diversity-related student groups or initiatives (see Table 7).

The provision of information about events, courses, student groups, centers, conferences, and similar entities requires systemic change, and therein lies the challenge. Beyond the need for quality online content is the reality that the work of diversity is considered overwhelmingly auxiliary and secondary (e.g., Caidi \& Allard, 2005; Gibson et al., 2017; Hudson, 2017; Hudson-Ward, 2014). Remedying the lack of representation and inclusion in LIS education necessitates deliberate, ongoing development. Until representation and 
inclusion scaffold our spaces, efforts toward equity, diversity, and social justice, though well-intended, will continue to be fleeting. To move beyond the dialogue and interest in ensuring that the LIS profession reflects the communities it serves, diversity-related content must be consistently and clearly displayed. LIS education would do well to transition from mere recruitment (outside-in) to reflection (inside-out); emulating egalitarian ideals in LIS spaces is one avenue for reshaping LIS education. There exists a vast amount of knowledge and interest in ensuring that the LIS profession is reflective of North America's diverse communities; this mantel must be integrated across platforms, courses, workspaces, and research.

Table 7. Percentage of program sites containing content

\begin{tabular}{lllllll}
\hline $\begin{array}{l}\text { Diversity } \\
\text { Statements }\end{array}$ & $\begin{array}{l}\text { Mission \& } \\
\text { Vision } \\
\text { Statements }\end{array}$ & $\begin{array}{l}\text { Diverse } \\
\text { Student } \\
\text { Groups }\end{array}$ & $\begin{array}{l}\text { Funding for } \\
\text { Students of } \\
\text { Diverse } \\
\text { Backgrounds }\end{array}$ & $\begin{array}{l}\text { Faculty } \\
\text { Profiles }\end{array}$ & $\begin{array}{l}\text { Diversity- } \\
\text { Related } \\
\text { Activities } \\
\text { \& News }\end{array}$ & $\begin{array}{l}\text { Diversity- } \\
\text { Related } \\
\text { Courses }\end{array}$ \\
\hline $\begin{array}{l}23 \% \\
(n=14)\end{array}$ & $84 \%$ & $40 \%$ & $81 \%$ & $100 \%$ & $69 \%$ & $78 \%$ \\
$(n=51)$ & $(n=25)$ & $(n=50)$ & $(n=61)$ & $(n=42)$ & $(n=48)$ \\
\hline
\end{tabular}

\section{Conclusion}

This article provides a starting point for assessing LIS websites in terms of how they represent their commitment to supporting diversity. Since prospective students, in the course of program evaluation, typically begin by scoping out programs online (Dam, 2014; Saichaie, 2014; Saichaie \& Morphew, 2014), websites play a vital role in presenting attractive educational options for students. Attending graduate school is a substantial career and financial undertaking, and the student-program fit is an important consideration for serious applicants.

A definite limitation of this study, however, lies in the potential disconnect between what a program says it does and what it actually does (Saichaie, 2014; Saichaie \& Morphew, 2014). From a marketing standpoint, the presence of diversity statements, information on student groups or funding for diverse students, and even diversity-related courses, initiatives, or partnerships may not be supported by systematic actions and concerted efforts. A program's appearance of goodwill does not evince that prospective students will encounter a department that is welcoming to diversity. Other factors such as a department's cohesiveness, campus climate, and student-advisor relationships may contribute to the actual educational experience (Lee, 2016).

This article is also limited by the bounds of the quantitative content analysis method (Pegoraro, 2006). Further qualitative inspection would be necessary to evaluate the caliber or attributes of diversity-related content. Qualitative data could improve the comprehensiveness of the findings. Similarly, the website content does not speak to ease of use and efficiency in locating available information. Moreover, some programs have little or no agency when it comes to managing their websites and must defer to their host institutions' web maintenance practices. Accreditation guidelines also influence program marketing. In the North American LIS context, the American Library Association mandates 
that programs provide current, accurate, and easily accessible information on curricula, faculty, admission requirements, criteria for evaluating student performance, assistance with placement, financial aid, and policies and procedures. While equity, diversity, and social justice are parallel to the latter aims (and are, indeed, recognized by the ALA 2015 Standards for Accreditation of Master's Programs in LIS), some programs may position concrete, accreditation-bearing metrics more prominently throughout their websites. This technicality may have impacted our results. Additionally, visual (e.g., photographs, logos) and audiovisual (e.g., podcasts; streamed open lectures) content can also represent equity, diversity, and social justice, although categorizing such media is nebulous.

We cannot satisfactorily explain why some LIS programs provide ample diversity-related content while others do not. It may suffice to say, however, that robust diversity-related language demonstrates the LIS field's pledge toward equity, diversity, and social justice. Where direct interaction with prospective students is not possible, a program's virtual image relays how its identity can affirm student identities. To the extent that a prospective student's attraction to LIS is contingent upon diversity outcomes, websites should speak to this commitment. More than this, diversity statements and other rhetorical declarations must translate into far-reaching, concrete measures to develop LIS programs with diversity frameworks in mind.

\section{Acknowledgements}

The authors wish to thank Dr. Lorraine Mon for the opportunity to take part in a special project that inspired extensive research on LIS program websites. 


\section{Appendix A}

\section{List of student organizations by type}

- DIVERSITY/SOCIAL JUSTICE (11)

- PLG Progressive Library Guild - Vancouver Student Chapter

- Diversity Council

- Progressive Librarians Guild- Toronto Student Chapter

- Activist Librarians and Educators

- Librarians for Social Justice

○ iDiversity Club

- Students of Color of Rackham Out in Science, Technology, Engineering, and Mathematics

○ CheckedOut: SILS Diversity

- Diversity Student Organization (DSO)

- Open Mind

$\circ \quad$ FLID - Future Librarians for Inclusivity and Diversity

- Progressive Librarians' Guild - Western Ontario Student Chapter

- $\quad$ ETHNICITY (9)

- Students of Color - Illinois

○ Multi-Ethnic Information eXchange (MIX)

- Students of Color - Michigan

- BLISTS: Black and Latino Information Studies Support

- KIT: Koreans in Information Technologies

- Nanhi Kali

- REFORMA Student Group

- Tribal Libraries, Archives, And Museums (TLAM) Student Group

- Students of Color - Simmons

- GENDER (12) 
- Women in Computing Society (WiCS)

- Association for Women in Science Movement of Underrepresented Sisters in Engineering and Science (MUSES)

- Advocating for Women in Technology (AWIT)

$\circ \quad$ Nothing is Binary

- Women at SICE (School of Informatics, Computing, and Engineering)

- Women in Information Technology and Informatics

- She Innovates

$\circ \quad$ WIT Graduate

○ SWEEP: Society for Women's Empowerment and Engagement Partners

- IT Girls United

○ Women Leading Kentucky

- Women in Information Science (WIS)

- INCARCERATED PERSONS (1)

○ Jail Library Group

- INTERNATIONAL LIBRARIES/LIBRARIANSHIP (6)

- Librarians Without Borders - British Columbia Student Chapter

- Librarians Without Borders - McGill Student Chapter

- Librarians without Borders - Western Ontario Student Chapter

- Student Chapter of ALA International Relations Round Table (SCIRRT)

- Librarians Without Borders - Maryland Student Chapter

- Librarians Without Borders - San Jose State Student Chapter

- PEER MENTOR/AMBASSADOR (5)

- Graduate Peer Mentors

- Student Ambassadors

- SICE Pacesetter

○ iDA (Information Diversity) Ambassadors 
- School of Information Studies Program Ambassadors

- SEXUALITY/GENDER IDENTITY (4)

- Queer Library Alliance

- Queer STS Club

- Spectra LGBTQ

- LGBTQ Library Group

\section{Appendix B}

List of diversity-related courses

$\bullet$

- $\quad$ Bibliography of Africa

- $\quad$ Building Literate Communities

- $\quad$ Change and Identity in Information Systems

- Communication and Community

- $\quad$ Communities and Values

- $\quad$ Community Building \& Engagement

- $\quad$ Community Building in Libraries

- $\quad$ Community Engagement Strategies in Information Science

- Community Informatics

- $\quad$ Community Partnerships

- $\quad$ Community Relations and Advocacy; Multicultural Librarianship

- $\quad$ Community Relations for Libraries

- $\quad$ Community-Led Services

- $\quad$ Creating Inclusive Environments

- $\quad$ Critical Making: Information Studies, Social Values, and Physical Computing

- $\quad$ Cultural Competence for Information Professionals 


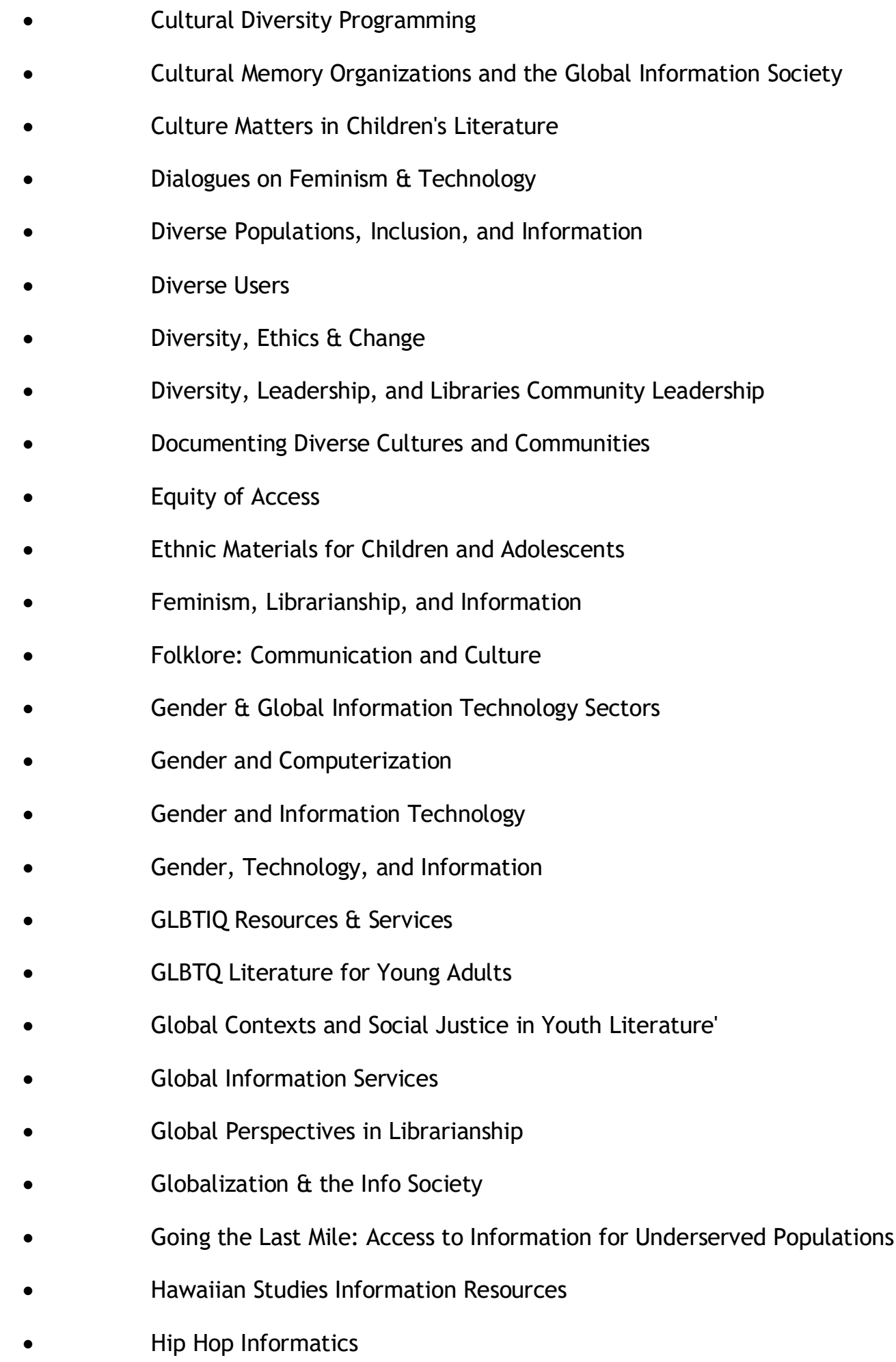

The International Journal of Information, Diversity, \& Inclusion, 2(3), 2018 


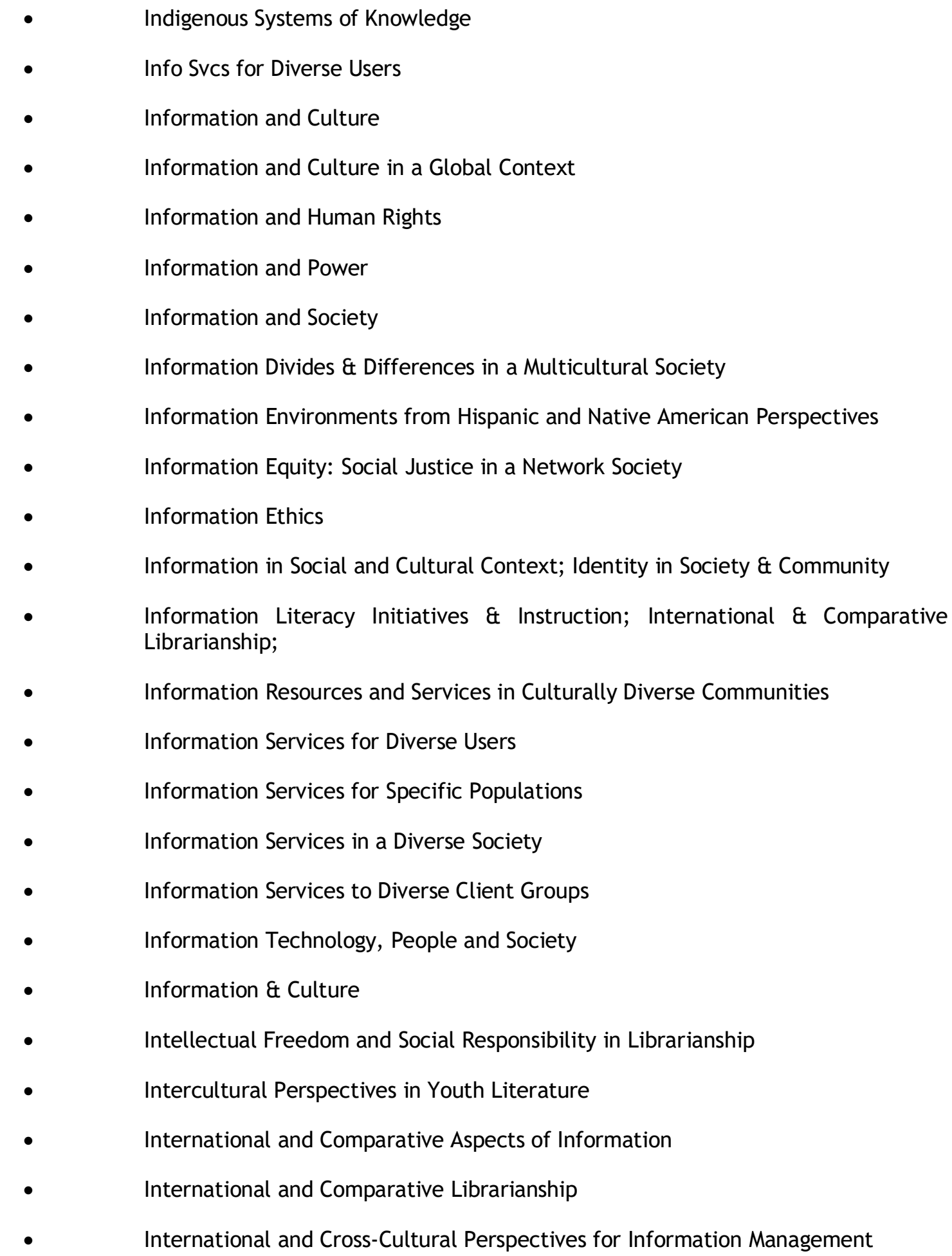




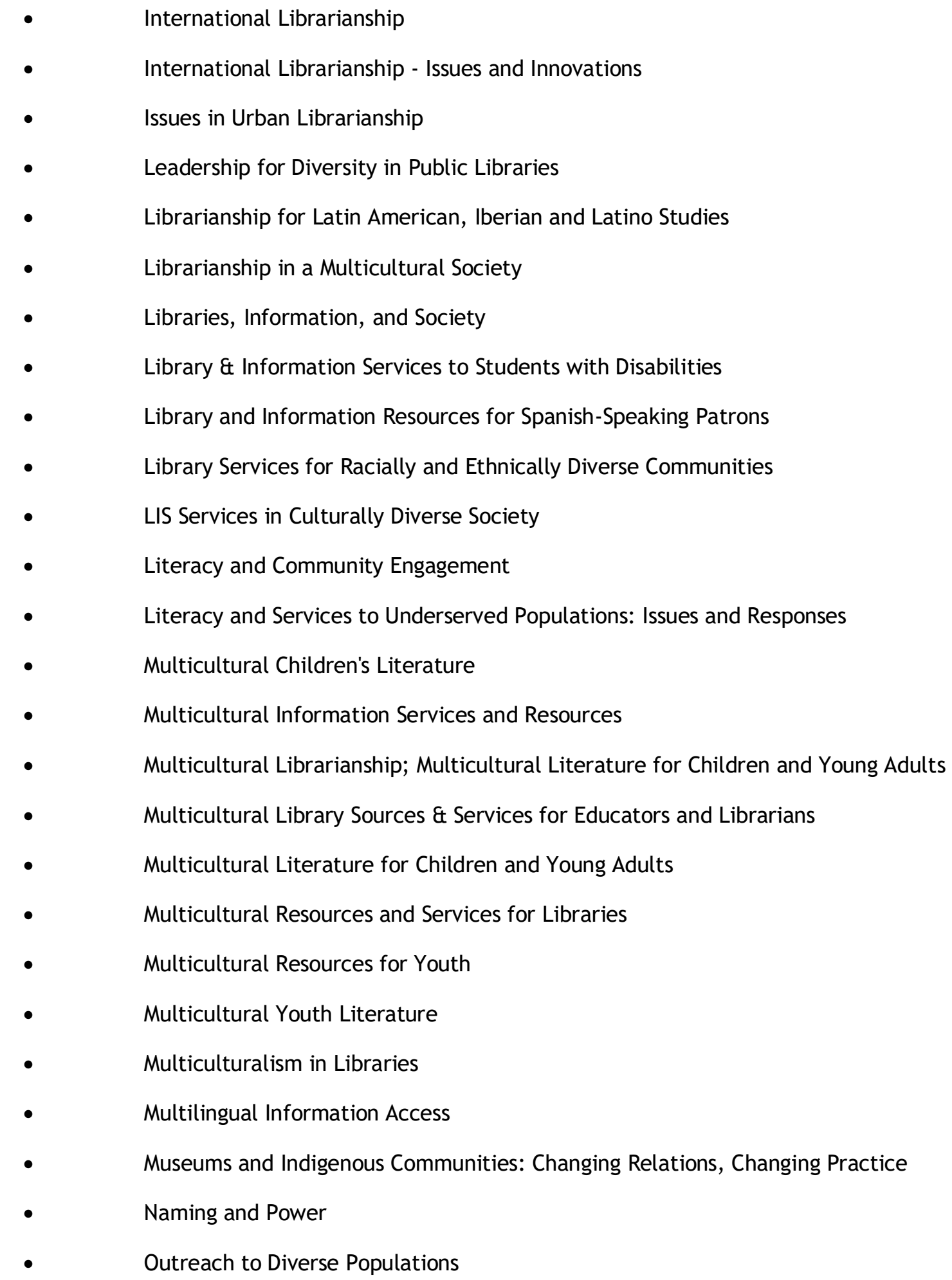

The International Journal of Information, Diversity, \& Inclusion, 2(3), 2018 ISSN 2574-3430, publish.lib.umd.edu/IJIDI/ 


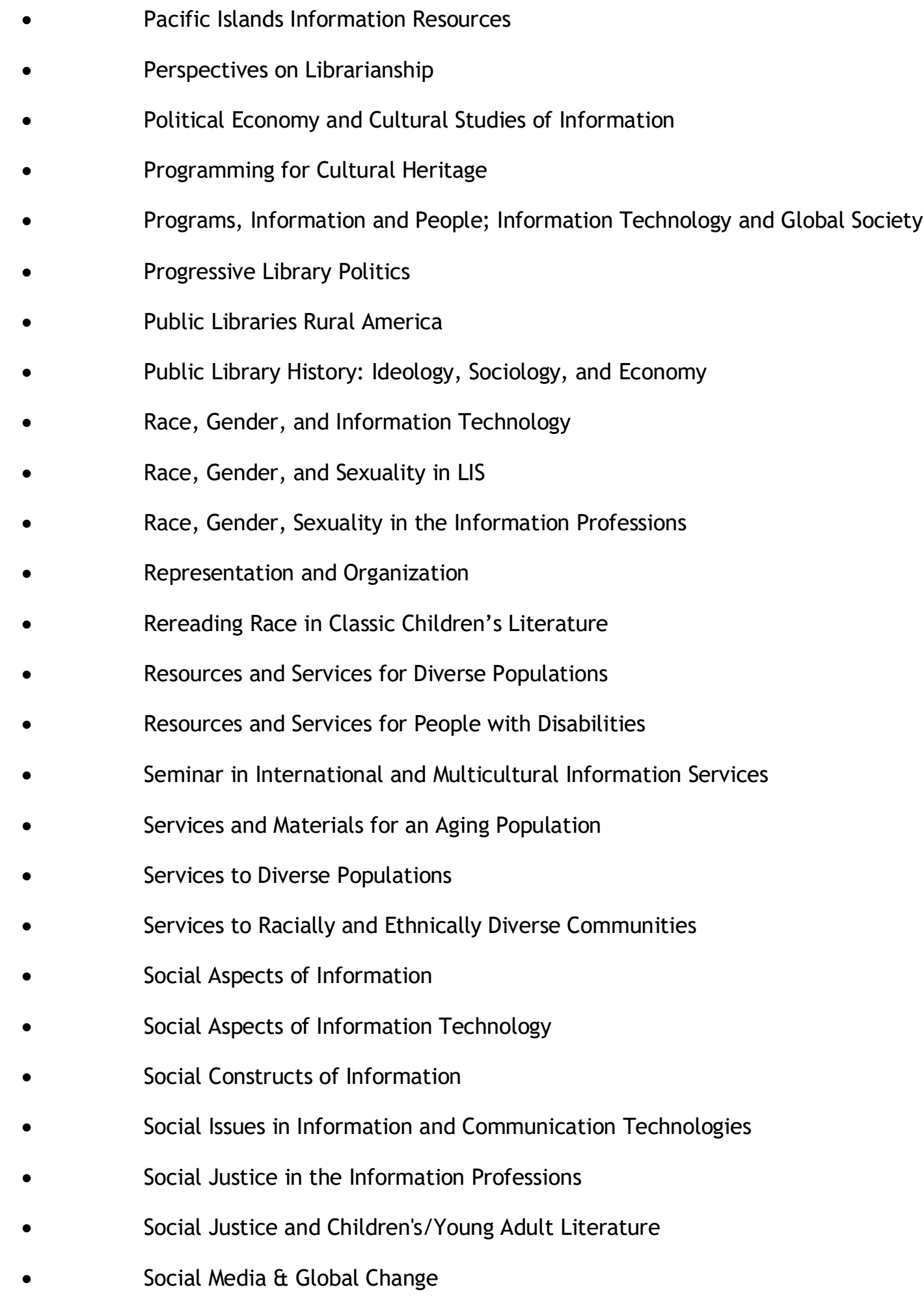




\begin{tabular}{|c|c|}
\hline • & Sociocultural Aspects of Literacy \\
\hline & Sources of Information for a Multicultural Society \\
\hline & Special Topics in Information Studies: Readings in Feminist Technology \\
\hline 死 & The African American Collection \\
\hline & The Digital Divide: Policy, Research, and Community Empowerment \\
\hline$\bullet$ & The Public Library in the Community: Developing a Critical Practice \\
\hline . & Topics in Race and Ethnicity in the Information Society \\
\hline & Universal Usability \\
\hline . & Values and Communities \\
\hline 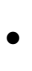 & Valuing Diversity: International and Intercultural Resources for Youth \\
\hline$\bullet$ & Who Writes Your Story? Race and Gender in the Archives \\
\hline D & Youth Services in a Diverse Society \\
\hline
\end{tabular}

\section{References}

Abdullahi, I. (2007). Diversity and intercultural issues in library and information science (LIS) education. New Library World, 108(9/10), 453-459.

Adkins, D., \& Espinal, I. (2004). The diversity mandate. Library Journal, 129(7), 52-54.

Allard, S., Mehra, B., \& Qayyum, A. M. (2007). Intercultural leadership toolkit for librarians: Building awareness to effectively serve diverse multicultural populations. Education Libraries, 30(1), 5-12.

American Library Association. (2017). Librarianship and library staff statistics. Retrieved from http://www.ala.org/research/librarystaffstats

Association for Library \& Information Science Education. (2017). 2016 Annual Statistical Report. Retrieved from http: / /www.alise.org/2016-statistical-report

Berelson, B. (1952). Content analysis in communication research. Glencoe, IL: Free Press.

Caidi, N., \& Dali, K. (2015). “Can we talk?”: Perceptions of diversity issues by students with diverse backgrounds, and a rumination on personal roads to systemic change. New Library World, 116(11/12), 748-780.

Caidi, N., \& Allard, D. (2005). Social inclusion of newcomers to Canada: An information problem? Library and Information Science Research, 27(3), 302-324. 
Cooke, N. A. (2013, September 25). Diversifying the LIS faculty (Backtalk column). Library Journal. Retrieved from http: / / j.libraryjournal.com/2013/09/opinion/backtalk/diversifying-the-lis-facultybacktalk/

Cooke, N. A. \& Sweeney, M. E. (2017). Teaching for justice: Implementing social justice in the LIS classroom. Sacramento, CA: Library Juice Press.

Dali, K. \& Caidi, N. (2016). A two-way street: Building the recruitment narrative in LIS programs. New Library World, 117(7/8), 499-539.

Dali, K. \& Caidi, N. (2017). Diversity by design: From concept to action. The Library Quarterly, 87(2), 88-98.

Dam, S. A. (2014). Factors influencing choice of a student affairs master's program (Master's Thesis). Retrieved from ProQuest Dissertations \& Theses Global database. (UMI 23987412)

Gibson, A., Chancellor, R. L., Cooke, N. A., Dahlen, S. P., Lee, S. \& Shorish, Y. (2017). Libraries on the frontlines: Neutrality and social justice. Equality, Diversity and Inclusion, 36(8), 751-766.

Greenberg, J. (1990). Organizational justice: Yesterday, today, and tomorrow. Journal of Management, 16(2), 399-432.

Gordon, J., \& Berhow, S. (2009). University websites and dialogic features for building relationships with potential students. Public Relations Review, 35(2), 150-152.

Hastings, S. K. (2015). If diversity is a natural state, why don't our libraries mirror the populations they serve? The Library Quarterly, 85(2), 133-138.

hooks, b. (1994). Teaching to transgress: Education as the practice of freedom. New York, NY: Routledge.

Hudson, D. (2017). On "diversity" as anti-racism in library and information studies: A critique. Journal of Critical Library and Information Science, 1(1). Retrieved from http://libraryjuicepress.com/journals/index.php/jclis/article/view/6

Hudson-Ward, A. (2014). Eyeing the new diversity: An emerging paradigm for recruitment and retention. American Libraries Magazine, 45(7/8), 32-36.

Kallio, R. E. (1995). Factors influencing the college choice decisions of graduate students. Research in Higher Education, 36(1), 109-124.

Kim, K., \& Sin, S. (2006). Recruiting and retaining students of color in LIS programs: Perspectives of library and information professionals. Journal of Education for Library and Information Science, 47(2), 81-95.

Kim, K. S., \& Sin, S. J. (2008). Increasing ethnic diversity in LIS: Strategies suggested by librarians of color. The Library Quarterly, 78(2), 153-177. 
Kirp, D. L. (2003). Shakespeare, Einstein, and the bottom line: The marketing of higher education. Cambridge, MA: Harvard University Press.

Jaeger, P. T., \& Franklin, R. E. (2007). The virtuous circle: Increasing diversity in LIS faculties to create more inclusive library services and outreach. Education Libraries, 30(1), 2026.

Jaeger, P. T., Subramaniam, M. M., Jones, C. B., \& Bertot, J. C. (2011). Diversity and LIS education: Inclusion and the age of information. Journal of Education for Library and Information Science, 52(2), 166-183.

Lance, K. C. (2005). Racial and ethnic diversity of U.S. library workers. American Libraries Magazine, 36(5), 41-45.

Lee, J. (2016). Information exchanged in mentoring between faculty advisors and their doctoral students (Doctoral dissertation). Retrieved from ProQuest Dissertations \& Theses Global database. (UMI 10120556)

Lloyd, M. (2007). The underrepresented Native American student: Diversity in library science. Library Student Journal, 2(1). Retrieved from http://www.librarystudentjournal.org/index.php/lsj/article/viewArticle/39/46

Maringe, F. (2006). University and course choice: Implications for positioning, recruitment and marketing. International Journal of Educational Management, 20(6), 466-479.

Marshall, C., \& Rossman, G. B. (1999). Designing qualitative research (3rd ed.). Thousand Oaks, CA: SAGE.

Mehra, B., \& Rioux, K. (2016). Progressive community action: Critical theory and social justice in library and information science. Sacramento, CA: Library Juice Press.

Morgan, J. C., Farrar, B., \& Owens, I. (2009). Documenting diversity among working LIS graduates. Library Trends, 58(2), 192-214.

Pegoraro, A. (2006). Using university websites for student recruitment: A study of Canadian university home pages examining relationship marketing tactics and website usability (Doctoral Dissertation). Retrieved from ProQuest Dissertations \& Theses Global database. (UMI 11235468)

Poock, M. C., \& Lefond, D. (2003). Characteristics of effective graduate school web sites: Implications for the recruitment of graduate students. College and University, 78(3), 15-19.

Rau, B. L., \& Hyland, M. M. (2003). Corporate teamwork and diversity statements in college recruitment brochures: Effects on attraction. Journal of Applied Social Psychology, $33(12), 2465-2492$.

Saichaie, K. (2011). Representation on college and university websites: An approach using critical discourse analysis. Des Moines, IA: The University of lowa.

Saichaie, K., \& Morphew, C. C. (2014). What college and university websites reveal about the 
purposes of higher education. The Journal of Higher Education, 85(4), 499-530.

Smith, L. V., Blake, J. J., Graves, S. L., Vaughan-Jensen, J., Pulido, R., \& Banks, C. (2016). Promoting diversity through program websites: A multicultural content analysis of school psychology program websites. School Psychology Quarterly, 31(3), 327-339.

Subramaniam, M. M., \& Jaeger, P. T. (2010). Modeling inclusive practice? Attracting diverse faculty and future faculty to the information workforce. Library Trends, 59(1), 109127.

Subramaniam, M. M., \& Jaeger, P. T. (2011). Weaving diversity into LIS: An examination of diversity course offerings in iSchool programs. Education for Information, 28(1), 1-19.

University of Tennessee. (2017). La SCALA. Retrieved from http://www.sis.utk.edu/LaSCALA

University of Arizona. (2017). Knowledge River. Retrieved from https: / / ischool.arizona.edu/knowledge-river-0

Wayne State University. (2017). Project IDOL. Retrieved from http://idol.slis.wayne.edu/

Web-based Information Science Education (WISE). (2016). Sample list of WISE courses. Retrieved from https: / / wiseeducation.org/static/docs/wise.pdf

Wilson, J. L., \& Meyer, K. A. (2009). Higher education websites: The "virtual face" of diversity. Journal of Diversity in Higher Education, 2(2), 91-102.

Ana Ndumu (avg05d@my.fsu.edu) earned a Ph.D. in Information at Florida State University's iSchool. Her dissertation focused on the information worlds of Black immigrants in the U.S. Her research interests include immigrant information behavior, diversity in LIS, and demography. Ana has over thirteen years of academic librarian and college instruction experience.

Crystal Betts-Green (cdb07f@my.fsu.edu) is a Ph.D. candidate in Information at Florida State University's iSchool. Her dissertation focuses on LGBTQ resources and patrons in rural libraries in the U.S. South. Her research interests include diversity in LIS education; graphic novels; intellectual freedom; social justice and radical librarianship; young adult and children's services; rural and small public libraries in the U.S. South; and information needs of diverse populations. She is also a Point Foundation LGBTQ Scholar. 